\title{
Wittgenstein and the Linguistic Turn
}

\author{
RICHARD RORTY, STANFORD
}

1.

There are profound differences of opinion among contemporary philosophers both about whether Wittgenstein is worth reading and about what one can learn from him. They parallel disagreements about whether, and in what sense, philosophical problems are problems of language. In this paper, I shall describe three views of Wittgenstein, corresponding to three ways of thinking about the so-called "linguistic turn in philosophy". Doing so will help me defend two claims for which I have argued in the past. First: there is no interesting sense in which philosophical problems are problems of language. Second: the linguistic turn was useful nevertheless, for it turned philosophers' attention from the topic of experience towards that of linguistic behavior. That shift helped break the hold of empiricism-and, more broadly, of representationalism.

Contemporary philosophers who call themselves "naturalists" typically see little value in Wittgenstein's work. For them, the central topic of philosophy is what Phillip Pettit calls, in Sellarsian language, the clash between "the manifest image" and "the scientific image". The manifest image incorporates what Pettit calls "the ideas that come with our spontaneous, everyday practices, such as the ideas we naturally have about freedom and consciousness, causation and law, value and duty". The scientific image, he says, "challenges us to look for where in that world there can be room for phenomena that remain as vivid as ever in the manifest image: consciousness, freedom, responsibility, goodness, virtue and the like."1.

Nothing in Wittgenstein's writings is of any help with what Pettit calls problems about the "place" of these phenomena in a world of physical particles. For these so-called "location problems" are the good old metaphysical ones-problems about how the really real is related to the merely apparently real. Those who, like myself, have been convinced by Wittgenstein that philosophy should dissolve such problems rather than solve them

\footnotetext{
${ }^{1}$ Pettit 2004, 308.
} 
regard the naturalists as reactionaries. They are turning their backs on advances that Wittgenstein helped us make.

Naturalists typically doubt that what Gustav Bergmann dubbed "the linguistic turn" was a good idea. Bergmann said that taking that turn was a result of the discovery that "the relation between language and philosophy is closer than, as well as essentially different from, that between language and any other discipline."2 Though many admirers of Wittgenstein still believe something like this, most naturalists do not. As Timothy Williamson has written, "there is a increasingly widespread sense that the linguistic turn is past".

Williamson remarks that, from the point of view of admirers of Wittgenstein, "the revival of metaphysical theorizing, realist in spirit" will look like "a throwback to pre-Kantian metaphysics". ${ }^{4}$ It does indeed. Williamson wants to break free of both Kantian and Wittgensteinian ways of thinking. Whereas Kant wanted philosophers to study thought rather than reality, Wittgenstein wanted them to study language. But, Williamson says, "perhaps one cannot reflect on thought or talk about reality without reflecting on reality itself... What there is determines what there is for us to mean". 5

Discussion of the issues that divide naturalists like Pettit and Williamson from admirers of Wittgenstein is complicated by disagreements about the import of Wittgenstein's work. Some Wittgensteinians take seriously his suggestion that what philosophers do "is to bring words back from their metaphysical to their everyday use" (PI 116) and his claim that "philosophy simply puts everything before us, and neither explains nor deduces anything" (PI 126) They cite the concluding passages of the Tractatus, and sections 89-133 of Philosophical Investigations, as evidence that Wittgenstein must not be thought of as offering any theses or theories about language, or about anything else. He was, on their view, exclusively a therapist.

Let us call the people I have just described "Wittgensteinian therapists". Their understanding of Wittgenstein's importance differs from that of philosophers who, as I do, find support in his writings for pragmatist views of truth and knowledge. Call these people "pragmatic Wittgensteinians".

\footnotetext{
${ }^{2}$ Bergmann ${ }^{2} 1992,64 f$.

${ }^{3}$ Williamson 2004, 106.

${ }^{4}$ Williamson 2004, 111.

${ }^{5}$ Williamson 2004, 111.
} 
They tend to brush aside just those passages that the therapists think most important-his dicta about the origin of philosophical problems and the need to abjure philosophical theorizing. The pragmatic Wittgensteinians think that their hero's importance consists in having replaced a bad theory about the relation between language and non-language, such as that offered in the Tractatus, with a better theory, the one offered in the Philosophical Investigations.

Neither the naturalists' location problems nor "analytic metaphysics", pragmatic Wittgensteinians say, will interest you unless hold two false beliefs. First: that language is a medium of knowledge only because it is tied down to non-language at certain particular points. Second: that the scientific image, by telling you what is really real, tells you what non-linguistic hitching-points are available. But Philosophical Investigations helped us see that this hitching-post idea can simply be dropped. On a pragmatic reading of that book, Wittgenstein is urging us to stop trying for what John McDowell calls "an external perspective" on language-a perspective enabling one to "view language side-ways on". If we could view it from that angle, we could spot the places where it hooks on to the world.

Wittgensteinian therapists agree with McDowell that one should not try for a sideways-on view. But they do not want to substitute an alternative view. They claim that Wittgenstein wants philosophers to engage in an activity called "elucidation", which is very different from that of propounding theses and backing them up with theories. To elucidate is not to replace one view of language by another, but to realize that any view about the relation between language and non-language is bound to be nonsense, and that philosophers who put forward such views have failed to attach a meaning to the words they use. On the therapists' reading, Wittgenstein was not telling us anything substantive, but rather conducting what he called "a battle against the bewitchment of our intelligence by means of language" (PI 109). Therapists accept his claim that "problems arising through a misinterpretation of our forms of language have the character of depth...their roots are as deep in us as the forms of our language and their significance is as great as the importance of our language". (PI 111)

The people who take this tack sometimes refer to themselves as "resolute readers" of Wittgenstein's works. Thomas Ricketts has applied this term to himself, Warren Goldfarb, Cora Diamond, James Conant, and various others. Readers of this sort accept the belief that Bergmann identified as the rationale for the linguistic turn in philosophy. They think that abandoning that belief amounts to repudiating Wittgenstein's most important 
contribution to philosophy. Pragmatic Wittgensteinians, by contrast, are accurately described by Edward Miner as treating "Wittgenstein's observations on philosophy as expressions of a very particular and idiosyncratic view of its nature, a position more or less detachable from his treatments of specific philosophical problems. $" 6$

Pragmatic Wittgensteinians tend to be historicist in their metaphilosophical views. They think that the problems of pre-Kantian metaphysics, the problems that the naturalists have revivified, are hangovers from a particular moment in Western intellectual history. These problems originate not in a clash between common sense and science, but rather between the immaterialist notions that Christian theology had inherited from Plato and Aristotle and the mechanistic and materialistic world-picture sketched by Galileo and Newton. That clash was between metaphysical outlooks, not between metaphysics and a premetaphysical understanding of things.

This clash produced the Cartesian notion of ideas as appearances on the stage of an inner theatre, as well as the Lockean account of words as signs of such ideas. More generally, it produced a picture of knowledge as an attempt to acquire accurate mental representations of non-mental reality. Representationalist accounts of the relation between language and nonlanguage emerged from the attempt to divide language into assertions that represent real things and those that do not. On this historicist view, Wittgenstein's importance lies in his having helped wrench us out of our Cartesian-Lockean mindset. He helped us overcome the temptation to ask "Which pieces of our language lock on to reality, and which do not?" On this pragmatic view of his achievement, he did not show metaphysics to be nonsense. He simply showed it to be a waste of time.

2.

I have been describing a three-cornered debate. In one corner are the naturalists, who want to get past the linguistic turn. In another are the pragmatic Wittgensteinians, who think that replacing Kantian talk about experience, thought, and consciousness with Wittgensteinian talk about the uses of linguistic expressions helps us replace worse philosophical theories with better ones. In a third are the Wittgensteinian therapists, for whom the importance of the linguistic turn lies in helping us realize that philosophers have failed to give meaning to the words they utter. The people in the first

\footnotetext{
${ }^{6}$ Minar 1995, 413.
} 
corner do not read Wittgenstein at all, and those in the other two read him very differently. I want now to describe the differences between these two readings in more detail.

The two camps disagree about the relation between early and later Wittgenstein. The therapists take the last pages of the Tractatus very seriously indeed. They do their best to tie them in with the metaphilosophical portions of Philosophical Investigations. In sharp contrast, the pragmatists tacitly dismiss the final passages of the Tractatus as an undigested residue of Schopenhauer. They regard sections 89-133 of the Investigations as an unfortunate left-over from Wittgenstein's early, positivistic period-the period in which he thought that "The totality of true propositions is the whole of natural science" (4.11). They have no more use for the claim that "The results of philosophy are the uncovering of one or another piece of plain nonsense" (PI 129) than for the earlier claim that "Most of the propositions and questions to be found in philosophical works are not false but nonsensical" (4.003).

Pragmatic readers of Wittgenstein are not much interested in his selfimage-his claim to be doing something radically different from what other philosophers do. In this respect they resemble pragmatic readers of Heidegger, who brush aside a distinction on which Heidegger insistedthat between mere philosophizing, which was what Heidegger's rivals and critics did, and a rarer and more important activity called "Thinking", in which he himself was engaged. Pragmatic Wittgensteinians do not see him as exemplary, either morally or methodologically. But they do think that he formulated an assortment of powerful and original criticisms of CartesianLockean views.

On their view, Wittgenstein's contribution to philosophy consists principally of the critique of ostensive definition, the private-language argument, and the rule-following argument. So the Tractatus strikes them as a false start. About all they can find to salvage from that book is its account of objects, as expounded by Ishiguro and McGuiness. What Anscombe called "linguistic idealism"- the idea that the essence of an object is determined by the sorts of thing we say about it--fits in well with an antiLockean, non-representationalist account of knowledge. For it chimes with Davidson's thesis that most of our beliefs about an object must be true, as well as with McDowell's argument that "since the world is everything that is the case...there is no gap between thought, as such, and the world".

${ }^{7}$ McDowell 1994, 27. Williamson quotes this passage disapprovingly in his "Past the linguistic turn" (here Williamson 2004), $109 f$. 
Pragmatic Wittgensteinians think that his really important contribution was to formulate arguments that anticipate, complement, and reinforce Quine's and Davidson's criticisms of the language-fact distinction, and Sellars' and Brandom's criticism of the idea of knowledge by acquaintance. On their view, comparing and contrasting the writings of these later philosophers with the Philosophical Investigations helps us filter out what is merely idiosyncratic in Wittgenstein's writings. Pragmatic Wittgensteinians do not want to recapture Wittgenstein's own way of thinking, but rather to restate his best arguments in more effective ways.

Naturalists sometimes refer to philosophers who are dubious about their revival of metaphysics as "Wittgensteinian quietists". ${ }^{8}$ But this label is more appropriate for Wittgensteinian therapists like Conant and Diamond than for pragmatic Wittgensteinians. The therapists treat "philosophy"as the name of a disease that can be cured by recognizing that one has been uttering nonsense. The pragmatists, however, are not interested in getting rid of philosophical problems as such. They are dubious about the claim that philosophical problems constitute a natural kind. They are focused on certain particular problems - those that came into prominence in the seventeenth century.

These problems no longer arise once a representationalist account of thought and language is replaced with a "social practice" account. To the pragmatists, it is a matter of indifference whether one says that the old problems are thereby dissolved or that they have now been solved. For Cartesian and Lockean ideas were, on the pragmatist view, no less clear and coherent than their replacements, just as the concepts of natural place and of phlogiston were no less coherent than those of gravity and of molecular motion. But, like their analogues in natural science, the older ideas did not pan out. They became more trouble than they were worth.

From the pragmatist's point of view, the positivists who initiated the linguistic turn in philosophy were wrong to think that there is a big difference between progress in empirical science and progress in philosophy. Consider the transition from Aristotelian hylomorphism to materialistic mechanism. Hylomorphism was neither nonsensical nor incoherent nor confused. Nor were the problems that Aristotelians discussed pseudoproblems. But those problems were forgotten once the advantages of the account offered by Galileo and Newton became evident. As with science, so with philosophy. Cartesian dualism, epistemological foundationalism,

\footnotetext{
${ }^{8}$ See Leiter 2004, 2f.
} 
and the fact-value distinction do not embody category mistakes, nor are they the results of conceptual confusion. They incorporated ideas that played an important part in intellectual progress. By now, however, it is time to replace them with better ideas.

Pragmatic Wittgensteinians think that the linguistic turn was an unnecessary detour. Mindful of Davidson's advice that we should cease to distinguish between knowing a language and knowing our way around in the world generally, they see no point in picking out something called "language" as the source of philosophical problems. On their view, both scientists and philosophers help us learn to get around the world better. They do not employ distinct methods. The only difference between them is that we call a new theory "scientific" if it facilitates prediction and "philosophical" if it does not.

But pragmatic Wittgensteinians agree with the therapists that there are some important links between early and late Wittgenstein. As Jose Medina puts it, "A crucial point of continuity in Wittgenstein's philosophy is the attempt to articulate a deflationary account of necessity that does away with the metaphysical view of necessity imagined as fact." 9 But they think that his later "social practice" view of necessity leaves the notion of "obtaining complete clarity' in the lurch. Once he had begun to treat the "hardness of the logical "must"" as internalized peer pressure--pressure to use words in certain ways in certain circumstances--it would have been better for Wittgenstein to have criticized the kind of philosophy he disliked on grounds of uselessness rather than as "nonsense".

In the Tractatus, the idea of rigid conditions for the meaningful use of an expression-conditions that we can get a clear view of-borrowed plausibility from the identification of the totality of true propositions with those used to state facts, the ones that compose the totality of the natural sciences. (Cf. 4.11) But once that restriction on the kind of expressions that can have a truth-value is dropped-once it is granted that moral judgments can be true in exactly the same way that empirical predictions can--it is hard to see how a sharp contrast between science and philosophy, or between philosophical discourse and other sorts of discourse, can survive.

In Wittgenstein's later work, no attempt is made to address what Popper called "the demarcation problem"- tracing the border between good science and bad metaphysics. Nor does he try to justify the linguistic turn. Rather, he simply contrasts "the everyday use" of expressions with their

\footnotetext{
${ }^{9}$ Medina 2002, 156.
} 
"metaphysical" use. (PI 116). The former is, we are told, an unconfused use, the latter a confused one. Wittgenstein writes as if his readers will find it obvious that thinkers like Descartes, Locke, Hegel, and Heidegger were victims of "the bewitchment of our intelligence by means of language" (PI 109) rather than original thinkers who, by using words in new ways, broke new paths of inquiry. He has no interest in putting himself in the shoes of the great dead philosophers, nor in treating them as responsive to the intellectual and sociopolitical exigencies of particular times and places.

In the language-game of the Tractatus, the contrast-term for both "metaphysics" and "nonsense" was "fact-stating, reality-picturing language". Later that role is taken over by "the everyday use of words". But we are told much less about everydayness in the later books than we were told about facts in the Tractatus. The everyday is described purely negatively. It is simply what philosophers are out of touch with. "Philosophy", in the metaphilosophical sections of the Investigations, means something like "discussion of problems created by the misuse of language". But the notion of "misuse of language", like that of "nonsense", strikes pragmatic readers of Wittgenstein as an explanation of the obscure by the more obscure.

3.

So much, for the moment, for the views of the pragmatic Wittgensteinians. I now want to offer a somewhat fuller account of the views of the therapists, the self-described "resolute readers". The most original and provocative claim that these readers make is that Wittgenstein never accepted the logical positivists' doctrine that philosophical problems arise out of misunderstandings of what they called "the logical syntax of language". He never believed that there was such a syntax. His version of the linguistic turn was as idiosyncratic as his aphoristic style. So he should not be put in the same box as Schlick, Carnap, Russell, and Ayer.

James Conant argues for this view by distinguishing between Frege's and Carnap's "substantial conception of nonsense" and Wittgenstein's own "austere" conception. Carnap explained the difference between "iggle piggle higgle" and Heidegger's "Das Nichts nichtet" as the difference between an utterance composed of signs in which no meaning can be perceived and a sentences composed of meaningful signs arranged in ways that violated syntactical rules. Conant argues, very persuasively, that Wittgenstein, when he wrote the Tractatus, did not believe that there were such things as 
"syntactical rules". So the only sort of nonsense that he could countenance was "mere nonsense", the sort exemplified by "iggle piggle higgle". Conant writes as follows:

Tractarian elucidation aims to show that these sentences that apparently express substantially nonsensical thoughts actually express no thoughts. ...The "propositions" we come out with when we attempt to formulate these problems are to be recognized as Unsinn. The only "insight" that a Tractarian elucidation imparts, in the end, is one about the reader himself: that he is prone to such illusions of thought....The illusion that the Tractatus seeks to dispel, above all, is that we can run up against the limits of language. ${ }^{10}$

Edward Witherspoon agrees with Conant, and cites a passage in Wittgenstein's Cambridge lectures of the 1930's. There Wittgenstein explicitly criticizes Carnapian attempts to distinguish two kinds of nonsense. He explicates this passage by noting that Carnapians "want to say that there are certain rules or conditions that these sentences do not conform to, and that they are therefore nonsense". But to do this they "have had to quasianalyze the utterance so as to show that it consists of meaningful concepts combined into a determinate quasi-logical form" ". By contrast, he says,

when Wittgenstein is confronted with an utterance that has no clearly discernible place in a language game, he does not assume that he can parse the utterance; rather, he invites the speaker to explain how she is using her words, to connect them with other elements of the language-game in a way that displays their meaningfulness... When Wittgenstein criticizes an utterance as nonsensical, he aims to expose, not a defect in the words themselves, but a confusion in the speaker's relation to her words-a confusion that is manifested in the speaker's failure to specify a meaning for them. (NW 345)

I have been persuaded by reading Conant, Witherspoon, Diamond, and other contributors to The New Wittgenstein, that Wittgenstein did indeed use "Unsinn" in a way different from either Frege or Carnap. I have also become convinced by them that Wittgenstein designed the Tractatus to be a self-consuming artifact. The recognition that the sentences of that book are Unsinn depends, as Conant puts it, "upon the reader's actually undergoing a certain experience", the attainment of which is "the sign that reader has understood the author of the work". ${ }^{12}$ Wittgenstein, Conant continues,

\footnotetext{
${ }^{10}$ Conant 2000, 197.

${ }^{11}$ Witherspoon 2000, 345.

${ }^{12}$ Conant 2000, 197.
} 
"does not call upon the reader to understand his sentences, but rather to understand him, namely the author and the kind of activity in which he is engaged-one of elucidation....When the elucidation has served its purpose, the illusion of sense is exploded from within". ${ }^{13}$

But though I am inclined to accept this as an accurate account of Wittgenstein's intentions, and am grateful to his resolute readers for providing it, I have no interest in undertaking the project Conant describes. My reaction to Wittgenstein's attempt to explode illusions of sense from within is the same as to Kierkegaard's attempt to escape from the aesthetic to the ethical, and then from the ethical to the consciousness of Sin: C'est magnifique, mais ce n'est pas la guerre. Admirers of Dewey like myself think that the point of reading philosophy books is not self-transformation but rather cultural change. It is not to find a way of altering one's inner state, but rather to find better ways of helping us overcome the past in order to create a better human future.

Despite their disagreements with Dewey, the positivists shared his conception of philosophy as a form of cultural politics. Carnap and Ayer thought that they might be able to make society more rational by formulating the rules that govern our use of language. They believed themselves to have acquired a superior grasp of those rules, thanks to their familiarity with symbolic logic. By spelling out those rules, they hoped to get undisciplined thinkers back on the rails. Their understanding of "the logical syntax of language" would enable them to draw a clear line between the cognitively meaningful and the cognitively meaningless. But once one gives up the notion that there is such a syntax, it is hard to see why one should take the linguistic turn. By turning his back on that notion, Wittgenstein may have made it impossible to defend Bergmann's claim that "the relation between language and philosophy is closer than, as well as essentially different from, that between language and any other discipline".

Nobody now thinks that the positivists' Kulturpolitisch initiatives bore fruit. If Carnap had been less eager to bring symbolic logic to bear, and a bit more patient, he could easily have connected "Das Nichts nichtet" with "other elements of the language-game in a way that displays its meaningfulness" (to use Witherspoon's phrasing). The language-game in question is one that Heidegger deliberately and self-consciously created. It is utterly implausible to think that Heidegger might have been led, by a process of elucidation, to find himself "confused about his relation to his own words".

${ }^{13}$ Conant 2000, 198. 
Like Descartes, Locke, Kant, Newton, and Einstein, he gave a technical sense to familiar terms, and invented neologisms, hoping thereby to expand our linguistic repertoire in ways that would bear fruit.

Pragmatists like myself typically find most of the language-games Heidegger invented unprofitable. We think it unlikely, for example, that there is anything useful to be said about the relation between Being and Nothing. But we also suspect that there is nothing interesting to be said about the distinction between sense and nonsense. If we adopt the social-practice view of language, there seems no way to reconstruct the relevant idea of "confusion". Anything will have a sense if you try hard enough to give it one. Nor will there be any way to identify a disease called "philosophy", one that needs to be elucidated away.

To see this point, it helps to consider the difference between the everyday use of epithets like "confused" and "nonsensical" and their technical use by Wittgensteinian therapists. When Descartes mocked the Aristotelian definition of motion ("the actualization of the potential qua potential") as unintelligible, he did not try to back up this charge with argument. The term "unintelligible" was just a rhetorical flourish. His point was simply that it would be better to treat "motion" as a primitive term than to try to synthesize mechanism with hylomorphism. When other fans of the New Science called various Scotist and Ockamite doctrines "nonsense" they did not mean that these authors had failed to attach meaning to the words they used. Rather, they used "nonsense" to mean something like "not worth bothering about, now that Aristotle has been dethroned by Galileo and Newton". "Useless" would have been as appropriate an epithet as "confused".

It was Kant who first made charges of confusion and senselessness more than casual polemical rhetoric. When he rebuked the natural theologians for misusing the terms "cause" and "substance", he backed up his point by argument. One such argument started off by exhibiting the antinomies created by the attempt to use those terms to describe non-spatiotemporal entities. These antinomies were already familiar, and Kant's originality lay in his attempt to erect a general theory about proper and improper use of concepts. This theory was put forward as the fruit of a newfangled discipline called "transcendental philosophy". Kant thought that we needed a general theory of representation if we were to understand what had gone wrong in the history of philosophy. By erecting one, he gave philosophy a new lease on life, and ensured its survival as an academic discipline. 
Kant's own theory, however, seemed to many of his critics to be more trouble than it was worth. To replace metaphysics with transcendental philosophy, they suggested, was to adopt a remedy as bad as the disease it claimed to cure. For this new kind of philosophy required one to take seriously what Strawson was to call "the mythical subject of transcendental psychology" - a mongrel discipline, neither logic nor psychology. It also required one to profess an understanding of the term "thing-in-itself" - a willingness that many who relished Kant's criticisms of both Hume and Leibniz were unable to muster.

When the initiators of the linguistic turn decided that it was time to draw a bright line between logic and psychology, they still wanted to do what Kant had failed to do: to put philosophy on the secure path of science. So they announced the discovery of a new discipline-one that would serve many of the same purposes as Kantian transcendental psychology, but would be "purely formal". This one--variously named "linguistic philosophy", "philosophy of language", and "a systematic theory of meaning"--would enable us to do what Kant had tried and failed to do. It would let us either solve or dissolve all the old philosophical problems. It could do this because it would be a theory not of representation in general, but of linguistic representation.

As a result of the popularity of the linguistic turn, "nonsense" became a term of philosophical art--just as "representation" had become one in the wake of Kant. Philosophers began to think of themselves as specialists in detecting nonsense. Philosophy's job would be done, they suggested, when all our concepts had been analyzed. All that we had to do was use some common sense, and some symbolic logic, and the traditional problems of philosophy would dissolve. Once we realized that the problems of philosophy were, in some sense or other, problems of language, all would be plain sailing.

But the failure of the positivists' intervention in cultural politics is now evident. The idea that philosophers should employ "linguistic methods" to expose the illusory character of philosophical problems has come to seem merely quaint. Despite the importance of Ryle's work in clearing the way for philosophers of mind such as Sellars, Dennett, and Davidson, nobody now wants to charge Descartes with having made a "category mistake". Nobody thinks he unhappily did not notice that statements about the mind are "mongrel categorical-hypotheticals". Nor does anyone nowadays see much point in Austin's maxim that "ordinary language is always the first word". Though many philosophers still accept the label "analytic", they no 
longer undertake to explain what a "philosophical analysis" of a concept is, nor by what rigorous standards alternative analyses are to be judged. They are content simply to argue for one or another philosophical theory, without claiming to wield special, specifically linguistic, methodological tools.

The transcendental turn and the linguistic turn were both taken by people who thought that disputes among philosophers might fruitfully be viewed from an Archimedean point outside the controversies these philosophers conduct. The idea, in both cases, was that we should step back from the controversy and show that the clash of theories is possible only because both sets of theorists missed something that was already there, waiting to be noticed. For Kant, they did not notice the limits set by the nature of our faculties. For those who initiated the linguistic turn, they failed to grasp the conditions of linguistic significance.

This "stepping back" move is hard to reconcile with the "social practice" view of language and thought that pragmatic readers find between the lines of the Investigations. That is the view epitomized in the Wittgensteinian maxim "Don't look for the meaning, look for the use". It is not a "use-theory of meaning", but rather a repudiation of the idea that we need a way of determining meanings. ${ }^{14}$ It sees the attempt to have such a theory as succumbing to the hope that language can be viewed sideways-on, making visible the hitching-posts at which language is tied to the world. Wittgenstein's maxims suggest to pragmatic readers that any utterance can be given significance by being batted around long enough in more or less pre-

\footnotetext{
${ }^{14}$ Davidson does not think that anybody should try to write out a T-theory for a natural language, nor that doing so would put us in a position to dissolve pseudo-problems. Brandom thinks that the content of an assertion is rarely, if ever, the same for any two users of the same linguistic expression. Neither invokes the claim that philosophical problems are problems of language. In "Wittgenstein's philosophy in relation to political thought", (included in The new Wittgenstein, cited above) page 131, Crary rightly says that if we view a "use-theory of meaning" as a view about how to fix meaning, then we should not attribute any such theory to Wittgenstein. Quite so, but neither should we attribute it to Davidson or Brandom.

Crary (ibid., 127) notes that I have come to repudiate the idea that philosophical views I dislike are "incoherent", but thinks that I am thereby committed to denying our "entitlement to certain epistemic ideals". Her criticism of me, and in particular of what she calls my "relativism", seems to depend upon attributing to me a view I would neither accept nor ascribe to Wittgenstein: that because use fixes meaning, and because meaning must change as use does, the boundaries between differing uses are "inviolable". Someone who accepts Brandom's inferentialist view of content, or Davidson's criticisms of the very idea of a conceptual scheme, has no use for the idea of inviolable barriers-barriers that further conversation cannot break down.
} 
dictable ways. One can distinguish more useful from less fruitful ways of speaking, and thus better scientific or philosophical theories from worse theories. But it is hard to make a place for Wittgenstein's notion of "disguised nonsense".

4.

Alice Crary explicitly rejects pragmatic appropriations of Wittgenstein. She thinks it a mistake to read Wittgenstein as having favored "certain metaphysical theses about the nature of logic and language in the Tractatus" and as having rejecting them later "in favor of something like their negations". ${ }^{15}$ The view she thinks wrong is pretty much the one I hold, but I would reformulate her statement of it by omitting both the word "metaphysical" and the phrase "the nature of". Pragmatists, at least those of my persuasion, would rather just say that Wittgenstein changed his mind about how best to talk about logic and language.

I suspect that Crary, Conant, and Diamond would reply that one cannot eschew metaphysics while still offering theories about the relation between language and reality. For Crary defines a metaphysical sentence as a one "presented from an external point of view on language". Presumably she regards "social practice" accounts of language such as Davidson's and Brandom's as so presented. She thinks that such a point of view is one "we aspire to or think we need to assume when philosophizing - a point of view on language as if outside from which we imagine we can get a clear view of the relation between language and the world." This, she says, is "no more than the illusion of a point of view". When we assume such a point of view "we don't wind up saying anything coherent about how things stand." 16

Pragmatic Wittgensteinians are willing to go along with this line of thought to the following extent: we agree that there is nothing useful to say about the relation between two large entities called "Language" and "World". We suspect that these entities are just the familiar, and rather disreputable, entities formerly known as "Subject" and "Object". There is, however, a lot to be said about our linguistic behavior. One example is Davidson's thesis that most of our beliefs must be true. Another is Brandom's explanation of why we have de re predication, and singular terms, in our language. A suitable selection of such holist and inferentialist doctrines

\footnotetext{
${ }^{15}$ Crary 2000, 4.

${ }^{16}$ Crary 2000, 6.
} 
is what I have been referring to, casually and for convenience of reference, as a "social practice" theory of language. This theory found much of its initial inspiration in Wittgenstein's critique of ostensive definition and of "knowledge by acquaintance".

Are Sellars, Davidson, McDowell and Brandom assuming "the illusion of a point of view"? I see no reason to think so. They do not seem to suffer from the "natural disappointment with the conditions of human knowledge" that Crary, following Stanley Cavell, says gives rise to "our tendency to become entangled in philosophical confusion". ${ }^{17}$ Their writings do not display any sign of ever having taken epistemological skepticism very seriously.

But Wittgensteinian therapists seem to agree with Cavell that such disappointment comes as naturally to us as does, according to Freud, Oedipal resentment. On this view, philosophy is not just one area of culture among others, an area some people find of interest and many others do not, but rather a trap into which anyone who begins to reflect is bound to fall. "The problems arising through a misinterpretation of our forms of language....are deep disquietudes". (PI 111)

I do not think that that sort of disappointment is widespread, but I do think that the therapists are on to something. That is the fact that many, though hardly all, people who find philosophy intriguing are in search of the ineffable-something that cannot be put into words. Sometimes this is for a vision of the Good or of God. In recent times, however, partially as a cause and partially as an effect of the linguistic turn in philosophy, it has expressed itself as a a desire for contact with "the World" that is not mediated through language. I think Wittgenstein felt this desire very deeply but recognized, early and late, that it could not possibly be fulfilled. So I think that Conant is on the right track when he says that "The aim of [the Tractatus] is to show us that beyond 'the limits of language' lies---not ineffable truth, but rather...einfach Unsinn, simply nonsense. ${ }^{18}$

Wittgenstein seems to have thought that the urge to penetrate beyond the effable, the need to break through language to something better, was more than just a relatively uncommon form of obsessional neurosis-one that he himself shared with certain other unfortunates. He apparently believed it to be part of the human condition. He thought that by looking more closely at the results of succumbing to this urge we might come to understand better what it is to be a human being.

\footnotetext{
${ }^{17}$ Crary 2000, 8.

${ }^{18}$ Conant 2000, 197.
} 
It is certainly true that the desire to get in touch with something that stays the same despite being described in many different ways keeps turning up in philosophy. Resistance to Wittgenstein's critique of ostensive definition, or to Putnam's doctrine of the relativity of reference, can easily be seen as manifestations of this desire. The need to shove language aside and get at reality "directly" reinforces the idea that demonstratives mark the location of hitching-posts, the places where language locks on to the world: "This is what we mean by red!".

The same desire, I think, underlies Kripke's attempt to use the expression "This very thing" as a way of pinning down an object independent of its description. It motivates Timothy Williamson's insistence that ontology is prior to philosophy of language because, pace Sellars, "In defining words - for example, natural kind terms-we must point at real specimens." ${ }^{, 19}$ It produces many other such attempts to find what Derrida called "a serene presence beyond the reach of play".

But it is not obvious that this desire, the one that sometimes manifests itself as the need to "emit an inarticulate sound" (PI 216) has deep roots. A desire may be shared by Parmenides, Meister Eckhart, Russell, Heidegger, and Kripke without being intrinsic to the human condition. Are we really in a position to say that this desire is a manifestation of what Conant calls "our most profound confusions of soul"? ${ }^{20}$ Wittgenstein was certainly convinced that it was. But this conviction may tell us more about Wittgenstein than about philosophy. The more one reflects on the relation between Wittgenstein's technical use of "philosophy" and its everyday use, the more he appears to have redefined "philosophy" to mean "all those bad things I feel tempted to do".

Such persuasive redefinitions of "philosophy" are characteristic of the attempt to step back from philosophy as a continuing conversation and to see that conversation against a stable, ahistorical background. Knowledge of that background, it is thought, will permit one to criticize the conversation itself, rather than joining in it. The Kantian transcendental turn and the later linguistic turn were, as I have already said, examples of such inevitably unsuccessful attempts to step out of the conversation. Kant could not answer the question of how he had managed to acquire so much nonempirical knowledge about the limits of thought. The philosophers who agreed with Bergmann that philosophical problems are problems of language were unable to cope with the fact that their accounts of "the logic of

\footnotetext{
${ }^{19}$ Williamson 2004, 111.

${ }^{20}$ Conant 2000, 196.
} 
language" were just practical suggestions about how it might be best for us to talk.

Once we give up on the project of "stepping back", we will think of the strange ways in which philosophers talk not as needing to be elucidated out of existence, but as suggestions for talking differently, on all fours with suggestions made by scientists and poets. A few philosophers, we may admit, are "like savages, primitive people, who hear the expressions of civilized men, and then draw the queerest conclusions from it". (PI 194) But most of them are not. They are, rather, contributors to the progress of civilization. Knowledgeable about the dead ends down which we have gone in the past, they are anxious that future generations should fare better. If we see philosophy in this historicist way, we shall have to give up on the idea that there is a special relation between something called "language" and something else called "philosophy".

Richard Rorty, May 24, 2006

\section{REFERENCES}

Bergmann, G. ${ }^{2} 1992$ "Logical positivism, language, and the reconstruction of metaphysics" reprinted in R. Rorty (ed.), The Linguistic turn: essays in philosophical method, University of Chicago Press, 64-65.

Conant, J. 2000 "Elucidation and nonsense in Frege and early Wittgenstein", in Crary / Read 2000.

Crary, A. / Read, R. (eds.) 2000 The New Wittgenstein, Routledge.

Crary, A. 2000 "Introduction", in Crary / Read 2000.

Leiter, B. 2004 "Introduction", in B. Leiter (ed.), The future for philosophy, Oxford.

McDowell, J. 1994 Mind and world, Harvard.

Medina, J. 2002 The unity of Wittgenstein's philosophy: necessity, intelligibility and normativity, State University of New York Press.

Minar, E. 1995 "Feeling at home in language", Synthese, 102.

Pettit, P. 2004 "Existentialism, quietism, and the role of philosophy", in B. Leiter (ed.), The future for philosophy, Oxford.

Williamson, T. 2004 "Past the linguistic turn", in B. Leiter (ed.), The future for philosophy, Oxford.

Witherspoon, E. 2000 "Conceptions of Nonsense in Carnap and Wittgenstein", in Crary / Read 2000. 
